\title{
Positive association of the androgen receptor CAG repeat length polymorphism with the risk of prostate cancer
}

\author{
CÉSAR PAZ-Y-MIÑO ${ }^{1}$, PAULO ROBLES ${ }^{1}$, CAROLINA SALAZAR ${ }^{1}$, PAOLA E. LEONE ${ }^{1}$, \\ JENNYFER M. GARCÍA-CÁRDENAS ${ }^{1}$, MANUEL NARANJO ${ }^{2}$ and ANDRÉS LÓPEZ-CORTÉS ${ }^{1}$ \\ ${ }^{1}$ Instituto de Investigaciones Biomédicas, Facultad de Ciencias de la Salud, Universidad de las Américas, Quito 170122; \\ ${ }^{2}$ Department of Pathology, Oncologic Hospital Solon Espinosa Ayala, Quito 170138, Ecuador
}

Received September 26, 2015; Accepted February 26, 2016

DOI: $10.3892 / \mathrm{mmr} .2016 .5414$

\begin{abstract}
Prostate cancer (PC) is the most frequently diagnosed cancer in Ecuador (15.6\%). The androgen receptor gene codes for a protein that has an androgen-binding domain, DNA-binding domain and N-terminal domain, which contains two polymorphic trinucleotide repeats (CAG and GGC). The aim of the present study was to determine whether variations in the number of repetitions of CAG and GGC are associated with the pathological features and the risk of developing PC. The polymorphic CAG and GGC repeat lengths in 108 mestizo patients with PC, 148 healthy mestizo individuals, and 78 healthy indigenous individuals were examined via a retrospective case-control study. Genotypes were determined by genomic sequencing. The results demonstrated that patients with $\leq 21 \mathrm{CAG}$ repeats have an increased risk of developing $\mathrm{PC}$ [odds ratio $(\mathrm{OR})=2.99,95 \%$ confidence interval $(\mathrm{CI})=1.79-5.01 ; \mathrm{P}<0.001]$. The presence of $\leq 21 \mathrm{CAG}$ repeats was also associated with a tumor stage $\geq \mathrm{T} 2 \mathrm{c}(\mathrm{OR}=4.75 ; 95 \%$ $\mathrm{CI}=1.77-12.72 ; \mathrm{P}<0.005)$ and a Gleason score $\geq 7(\mathrm{OR}=2.9$; 95\% $\mathrm{CI}=1.1-7.66 ; \mathrm{P}=0.03)$. In addition, the combination of $\leq 21$ $\mathrm{CAG}$ and $\geq 17$ GGC repeats was associated with the risk of developing $\mathrm{PC}(\mathrm{OR}=2.42 ; 95 \% \mathrm{CI}=1.38-4.25 ; \mathrm{P}=0.002)$ and with tumor stage $\geq \mathrm{T} 2 \mathrm{c}(\mathrm{OR}=2.77 ; 95 \% \mathrm{CI}=1.13-6.79 ; \mathrm{P}=0.02)$. In conclusion, the histopathological characteristics and PC risk in Ecuadorian indigenous and mestizo populations differs in association with the CAG repeats, and the combination of CAG and GGC repeats.
\end{abstract}

Correspondence to: Dr César Paz-y-Miño or Mr. Andrés López-Cortés, Instituto de Investigaciones Biomédicas, Facultad de Ciencias de la Salud, Universidad de las Américas, Jose Queri Street and Granados Avenue, Quito 170122, Ecuador

E-mail: cesar.pazymino@udla.edu.ec

E-mail: aalc84@gmail.com

Key words: androgen receptor gene, Ecuador, mestizo, indigenous, polymorphic trinucleotide repeats, prostate cancer

\section{Introduction}

Prostate cancer (PC) represents a significant health problem that involves hormonal, environmental, genetic and hereditary factors. PC is the second most commonly diagnosed type of cancer in males, representing $15 \%$ of all new cancer cases in 2015 (1,114,072 cases) (1). Worldwide, the areas with a higher incidence of PC cases per 100,000 inhabitants are Oceania (101.9), North America (97.2) and Western Europe (94.9) (1-3). In Ecuador, $33 \%$ of all carcinoma diagnoses in males are prostate cancer, with an increase in the incidence from 23.7 per 100,000 inhabitants in 1985 to 54.4 in 2012 (1-4). Furthermore, the mortality rate associated with PC was 18.12 per 100,000 inhabitants in Ecuador in 2012 (1-5).

The prostate is an androgen-dependent organ whose cell cycle is mediated by the interaction between the receptor and androgens. Genes that are involved in the signaling pathways and metabolism of these hormones have been implicated as factors involved in the initiation or progression of prostate adenocarcinoma (6). The androgen receptor (AR) gene is located on chromosome Xq12 and encodes a protein that has three major functional domains: The $\mathrm{N}$-terminal domain (NTD), DNA-binding domain and ligand-binding domain (Fig. 1A) (7). The NTD, encoded by exon 1, regulates the transactivation of target genes and contains two polymorphic trinucleotide repeats: CAG and GGC, encoding polyglutamine and polyglycine, respectively (Fig. 1B) (7). The length of the CAG repeats correlates inversely with the AR transactivation function $(8,9)$. In certain studies, a low number of CAG repeats has been associated with an increased risk of PC (10-14). However, other groups have not identified these repetitions as a risk factor, suggesting that this factor is less relevant (15-17). The effects of GGC repeats on transcription are also unclear $(18,19)$. Certain studies have demonstrated an association of short GGN or GGC repeats with PC $(13,14)$, while others have demonstrated a correlation with long repeats (20), and the majority of studies have not been able to establish any association with risk or protection $(15,21)$.

The variants reported in the CAG and GGC repeats are highly polymorphic and associated with ethnic factors, thus, it may be important to determine their association with PC in different populations. The present study analyzed the polymorphic CAG and GGC repeats as possible risk factors for 
the development of PC in the Ecuadorian mestizo population. Since Ecuador is ethnically diverse, the number of repetitions was also determined in indigenous populations of the Andean region.

\section{Materials and methods}

Biological samples. The Bioethics Committee of the University of the Americas (Quito, Ecuador) approved this retrospective case-control study following the Declaration of Helsinki. This study was performed to determine the association between CAG and GGC repeats and the risk of PC and histopathological characteristics of prostate tumors.

A total of 334 individuals were analyzed; 108 mestizo patients had a clinical diagnosis of prostate adenocarcinoma and 148 mastizo patients were healthy. Additionally, 78 healthy indigenous individuals were analyzed to determine the variety of trinucleotide repeats between different ethnic groups. The tumor samples were obtained from the Department of Pathology at the Carlos Andrade Marin Hospital (Quito, Ecuador) and the Oncological Hospital Solon Espinoza Ayala (Quito, Ecuador) from 2006 to 2008. Each case history conferred relevant information, such as age at diagnosis, preoperative prostate specific antigen levels (PSA), Gleason score, pTNM (tumor, nodule, metastasis), seminal vesicle invasion and surgical margin. The control group was selected randomly during the health check. They presented ethnic and geographical similarity to the affected individuals. Moreover, the controls did not have a history of cancer, exposure to genotoxics or consumption of alcohol or tobacco usage. Samples of the native population were collected from individuals who were self-recognized as indigenous from the Carchi, Imbabura, Cotopaxi, Bolivar, Cañar and Azuay Andean provinces; and the Canari, Otavalo, Pasto, Karanki, Kichwa and Wuarango communities. Furthermore, all participants included in the study signed an informed consent form.

DNA extraction and purification. DNA extraction and purification of case and control sample was performed using the PureLink Genomic DNA kit (Invitrogen; Thermo Fisher Scientific, Inc., Waltham, MA, USA). The DNA of the affected individuals, which presented an average concentration of $80 \mathrm{ng} / \mu \mathrm{l}$, was extracted from ten sections $(5 \mu \mathrm{m})$ of formalin-fixed paraffin-embedded prostate tumor tissue previously cut with a CUT 6062 microtome (SLEE, Mainz, Germany) and removed with Xylol. The DNA of the healthy mestizo individuals and the healthy indigenous individuals was extracted from peripheral blood samples and buccal swabs, respectively. The average concentration was $135 \mathrm{ng} / \mu \mathrm{l}$ as determined using a NanoDrop 2000 (Thermo Fisher Scientific, Inc.).

Genotyping. Genotyping was performed using the polymerase chain reaction (PCR) technique and DNA sequencing analysis. A final volume of $50 \mu 1$ DNA was used for each PCR reaction for the trinucleotide repeat polymorphisms $\mathrm{CAG}$ and GGC. Each reaction consisted of $4 \mu \mathrm{l}$ DNA template (50-100 ng), $0.2 \mu \mathrm{M}$ of each deoxynucleotide triphosphate (dNTPs), $3 \mathrm{mM} \mathrm{MgCl}_{2}, 5 \mu \mathrm{l}$ of $10 \mathrm{X}$ buffer $(500 \mathrm{mM} \mathrm{KCl}$ and $200 \mathrm{mM}$ Tris-HCl, $\mathrm{pH}$ 8.4), 0.5 units of AccuPrime kit GC-Rich DNA Polymerase (Invitrogen; Thermo Fisher Scientific, Inc.), $0.0008 \mathrm{mmol} / 1$ dimethyl sulfoxide, $34 \mu 1$ Milli-Q water and $0.4 \mu \mathrm{M}$ of each primer. The primer sequences were as follows: Forward, 5'-TCCAGAATCTGTTCCAGAGCG TGC-3' and reverse, 5'-GCTGTGAAGGTTGCTGTTCCT CAT-3' for the CAG repeats; and forward, 5'-TCCAGAATC TGTTCCAGAGCGTGC-3' and reverse, 5'-GCTGTGAAG GTTGCTGTTCCTCAT-3' for the GGC repeats.

The amplification program of the polymorphic $\mathrm{CAG}$ repeat length consisted of $5 \mathrm{~min}$ at $95^{\circ} \mathrm{C}$, followed by 32 cycles of $45 \mathrm{sec}$ at $95^{\circ} \mathrm{C}, 30 \mathrm{sec}$ at $61^{\circ} \mathrm{C}, 30 \mathrm{sec}$ at $72^{\circ} \mathrm{C}$, and $5 \mathrm{~min}$ at $72^{\circ} \mathrm{C}$. The amplification program of the polymorphic GGC repeat length consisted of $2 \mathrm{~min}$ at $95^{\circ} \mathrm{C}$, followed by 28 cycles of $30 \mathrm{sec}$ at $95^{\circ} \mathrm{C}, 30 \mathrm{sec}$ at $59^{\circ} \mathrm{C}, 45 \mathrm{sec}$ at $72^{\circ} \mathrm{C}$, and $5 \mathrm{~min}$ at $72^{\circ} \mathrm{C}$. Each run was completed using a Sure Cycler 8800 thermocycler (Agilent Automation Solutions, Santa Clara, CA, USA).

The products obtained were genotyped through sequence analysis using a Genetic Analyzer 3130 (Applied Biosystems, Austin, TX, USA). The final volume of each reaction was 9.8 $\mu \mathrm{l}$ and contained $2.8 \mu \mathrm{l}$ Milli-Q water, $2 \mu \mathrm{l}$ of $5 \mathrm{X}$ buffer, $1 \mu \mathrm{l}$ forward primers (3.2 pmol), $1 \mu \mathrm{l}$ BigDye Terminator v3.1 sequencing standard (Applied Biosystems), and $3 \mu \mathrm{l}$ of PCR product (3-10 ng). Once the product was amplified, it was then purified using Agentcourt Cleanseq (Beckman Coulter, Miami, FL, USA). The amplification program consisted of $3 \mathrm{~min}$ at $96^{\circ} \mathrm{C}$, followed by 30 cycles of $10 \mathrm{sec}$ at $96^{\circ} \mathrm{C}, 5 \mathrm{sec}$ at $50^{\circ} \mathrm{C}$, and $4 \mathrm{~min}$ at $60^{\circ} \mathrm{C}(22)$. Finally, sequence analysis was performed using Sequencing Analysis Software 5.3.1 (Applied Biosystems), and the alignment with sequences from GeneBank (AR NC_000023) was performed using Seq-Scape Software v2.6 (Applied Biosystems).

Statistical analysis. The information from the clinical records of the patients was collected and stored in a database. The frequency of the GGC-CAG repeats in the three study groups was determined by descriptive statistical analysis. In the case-control study, samples from the indigenous population were not included as there were no prostate tumor sections from indigenous patients. The CAG and GGC repeats were categorized into two groups ( $\leq 21$ vs. $\geq 22$ and $\leq 16$ vs. $\geq 16$, respectively). Categories were used according to those in previous studies, analyzed separately and combined $(15,16)$.

The association between the number of repetitions with the risk of developing PC and with the pathological characteristics tumor stage $(<\mathrm{T} 2 \mathrm{c}$ vs. $\geq \mathrm{T} 2 \mathrm{c})$, Gleason score (2-6 vs. $7-10)$, PSA (<20 vs. $\geq 20$ ), surgical margins and vesicular invasion (present vs. absent) was determined by odds ratio (OR), 95\% confidence interval (CI), $2 \times 2$ contingency tables and the $\chi^{2}$ test. $\mathrm{P}<0.05$ was considered to indicate a statistically significant difference. These analyses were performed using IBM SPSS Statistics 22 software (IBM, Armonk, NY, USA).

\section{Results}

Clinical characteristics of study participants. Clinical information of the 108 cases of prostate cancer is detailed in Table I. The mean age at diagnosis was 69 years. Of these 
A

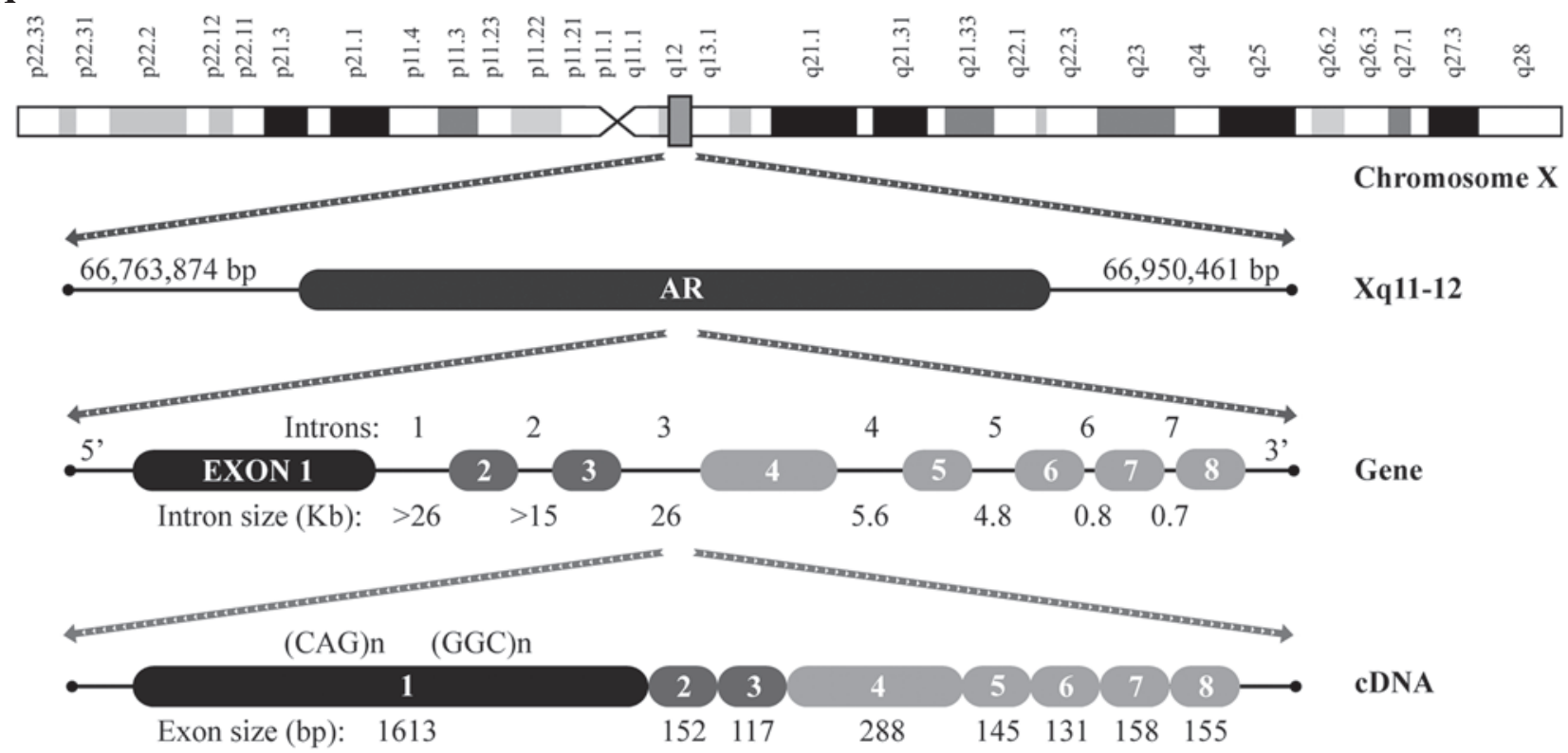

B

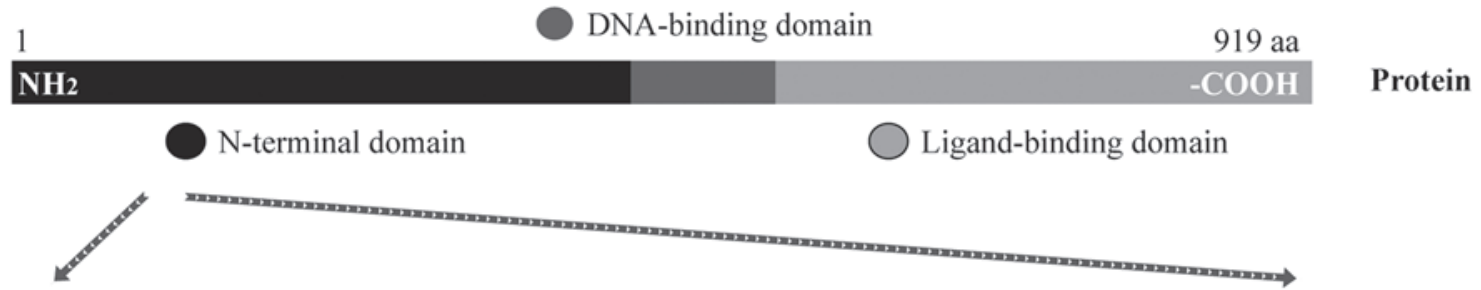

Affected mestizo individuals (12 to 30), average 20 repeats 00000000000000000000

CAG repeats Healthy mestizo individuals (16 to 30), average 22 repeats 0000000000000000000000

Polyglutamine

Healthy indigenous individuals (18 to 29 ) average 24 repeats 00000000000000000000000

Affected mestizo individuals (13 to 18$)$, average 16 repeats

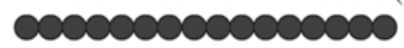

- GGC repeats

Healthy mestizo individuals (15 to 18), average 17 repeats

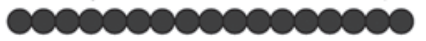

Polyglicine

Healthy indigenous individuals (14 to 18 ) average 17 repeats

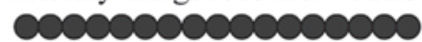

Figure 1. Androgen receptor gene. (A) Genetic structure of the androgen receptor gene on chromosome X. (B) Analysis of polymorphic CAG and GGC repeat lengths in Ecuadorian indigenous and mestizo populations.

patients, there was information for 87 individuals $(81 \%)$ concerning the tumor stage and Gleason level, $27(25 \%)$ in relation to the invasion of seminal vesicles and $94(87 \%)$ regarding PSA levels. From all the cases, only $8(7.41 \%)$ had metastases to organs, such as the testes, liver, skull, sternum and spine.

Determination of CAG repeats. Regarding the CAG repeats, the patient group presented with 12-30 repetitions with an average of 20. The most common number of CAG repeats were 21 and 22 (15.7 and 12\%, respectively). The mestizo control group had 16-30 repetitions with an average of 22 . The most common number of CAG repeats were 22 (25.7\%) and 25
$(12.8 \%)$. In the indigenous population, the repeat size ranged from 18 to 29 CAGs, determining the highest average of the three groups corresponding to 24 repetitions (Fig. 1B). Thus, the most common number of CAG repeats were 24 and 26, both with $24.4 \%$. Statistically significant differences $(\mathrm{P}<0.001)$ in the distribution of these trinucleotides were demonstrated ( $\leq 21$ CAGs vs. $\geq 22$ CAGs).

Determination of $G G C$ repeats. The total number of individuals analyzed for GGC repeats was 321 consisting of 243 mestizos (108 cases and 135 controls) and 78 indigenous individuals. In patient samples, the number of GGC trinucleotide repeats ranged from 13 to 18 , with an average of 16 . The most 
Table I. Distribution of baseline characteristics (at diagnosis) in all patients with prostate cancer.

\begin{tabular}{|c|c|c|}
\hline Parameter & $\begin{array}{l}\text { Number of } \\
\text { patients (n) }\end{array}$ & $\begin{array}{c}\text { Percentage } \\
(\%)^{\mathrm{a}}\end{array}$ \\
\hline \multicolumn{3}{|c|}{ Age, years $(n=108)$} \\
\hline $46-58$ & 16 & 15.0 \\
\hline $59-70$ & 42 & 39.0 \\
\hline $71-82$ & 35 & 32.0 \\
\hline $83-93$ & 15 & 14.0 \\
\hline \multicolumn{3}{|c|}{ Tumor stage $(n=87)$} \\
\hline $\mathrm{T} 1-\mathrm{T} 2 \mathrm{~b}$ & 39 & 44.8 \\
\hline $\mathrm{T} 2 \mathrm{c}-\mathrm{T} 4$ & 48 & 55.2 \\
\hline \multicolumn{3}{|c|}{ Gleason score $(n=87)$} \\
\hline $2-6$ & 46 & 52.9 \\
\hline 7 & 16 & 18.4 \\
\hline $8-10$ & 25 & 28.7 \\
\hline \multicolumn{3}{|c|}{ PSA, ng/ml (n=94) } \\
\hline $0-4$ & 8 & 8.5 \\
\hline $4.1-10$ & 24 & 25.5 \\
\hline $10.1-20$ & 22 & 23.4 \\
\hline 20 & 40 & 42.6 \\
\hline \multicolumn{3}{|c|}{ Seminal vesicle invasion $(n=27)$} \\
\hline Present & 7 & 25.9 \\
\hline Absent & 20 & 74.1 \\
\hline \multicolumn{3}{|c|}{ Positive surgical margins $(n=69)$} \\
\hline Affected & 10 & 14.5 \\
\hline Free & 59 & 85.5 \\
\hline \multicolumn{3}{|c|}{ Metastasis $(n=108)$} \\
\hline Present & 8 & 7.4 \\
\hline Absent & 100 & 92.6 \\
\hline
\end{tabular}

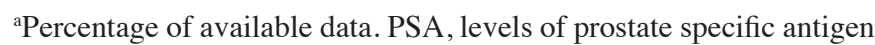
at diagnosis.

common number of GGC repeats were $16(25 \%)$ and $17(12 \%)$. The mestizo control group had between 15 and 18 repeats, with an average of 17 . The most common number of GGC repeats were $16(17.8 \%)$ and $17(59.3 \%)$. The indigenous population had between 14 and 18 repetitions with an average of 17 (Fig. 1B). The most common number of GGC repeats were $17(50 \%)$ and 18 (24.4\%). The difference in the distribution of the GGC repeats in the three study groups was statistically significant $(\mathrm{P}<0.05)$.

OR of $C A G$ and GGC repeats. Table II shows the OR of $\leq 21$ CAGs and $\leq 16$ GGCs independently and in combination $(\leq 21 \mathrm{CAGs}$ plus $\leq 16 \mathrm{GGCs}$, and $\leq 21 \mathrm{CAGs}$ plus $\geq 17$ GGCs), in association with $\mathrm{PC}$ in the mestizo population. The comparison between $\leq 21 \mathrm{CAGs}$ and $\geq 22 \mathrm{CAGs}$ demonstrated an OR of 2.99 (95\% CI, 1.79-5.01; P<0.001). The comparison between GGC repeats was not statistically significant. Additionally, the combination of the repetition ranges demonstrated an increased risk when comparing $\leq 21 \mathrm{CAGs} / \geq 17$ GGCs with the other alleles (OR=2.42; 95\% $\mathrm{CI}=1.38-4.25 ; \mathrm{P}=0.002$ ).

Association of CAG and GGC repeats with clinical characteristics of $P C$. In relation to tumor clinical characteristics, the presence of $\leq 21$ CAGs showed significant association with tumor stage $(\mathrm{OR}, 4.75 ; 95 \% \mathrm{CI}, 1.77-12.72 ; \mathrm{P}<0.05)$ and Gleason score (OR, 2.9; 95\% CI, 1.1-7.66; $\mathrm{P}=0.03$; Table III); as in the ratio of risk of prostate cancer.

Table IV demonstrated the association between combinations $\mathrm{CAG}+\mathrm{GGC}$ and pathological characteristics. The association between the trinucleotide combination $\leq 21$ CAGs $+\geq 17$ GGCs and the tumor stage (T1-T2b compared with T2c-T4) demonstrated an OR of 2.77 (95\% CI, 1.13-6.79; $\mathrm{P}=0.02$ ), whereas the combination $\leq 21 \mathrm{CAGs}+\leq 16$ GGCs demonstrated no significant association. Additionally, there was no significant association between the trinucleotide combinations and the Gleason grade, PSA, surgical margins, or seminal vesicle invasion.

\section{Discussion}

Trinucleotide repeats are associated with human diseases and microsatellite instability (23). Microsatellite instability affects gene expression and protein function (24). In addition to $\mathrm{PC}$, the polymorphic CAG repeats have been associated with skin disorders $(25,26)$, breast cancer, polycystic ovary disease, Kennedy syndrome $(27,28)$, azoospermia and oligospermia (29). Furthermore, the effects of the repetition sequence GGC polyglycine have been associated with hypospadias and cryptorchidism $(30,31)$; however, its role in transcription is unclear.

The CAG and GGC repeats specifically vary depending on the ethnic group studied $(32,33)$. The normal distribution of the CAG repeats is reported in a range of 6-39, with an average of 19-20 in African-Americans, 21-22 in Caucasians, 22-23 in Asians, and 23 in Hispanics (34). In this study, the repeat range in the mestizo control group was 16-30, with an average of 22, resembling Asians and Caucasians. Other polymorphisms associated with PC in Ecuador also showed similar frequencies to Asians $(35,36)$. Regarding South American countries, Brazil reported an average of 20.65 CAGs for a population of Caucasian and African descents (37). In another study, Madjunkova et al (38) reported a mean repeat length of 21.5 CAGs in patients with PC from Macedonia. In a study that examined adenocarcinomas, the number of CAG repeats ranged from 12 to 30 and averaged 20, which was similar to that in a healthy Brazilian population. Moreover, these results were consistent with the average in cases (19 CAGs) and controls (19-20 CAGs) in African-Americans (17), and in both, cases and controls (21.95 CAG) in Australians (39).

The variation in the number of the GGC trinucleotides has also been demonstrated in several populations, however, it is less polymorphic than the CAG repeat (40). In this study, the repeat range was 15-18 with an average of 17 GGCs for controls. These data are consistent with the normal range found in $90 \%$ of the world population (20). The repeat average is 14-15 in African-American and African natives (14), 16 in Asians (10), and 15-16 in Caucasian, European and Mediterranean populations (40). GGC repeats $<17$ in controls have also 
Table II. Association between polymorphic CAG and GGC repeats and prostate cancer risk among cases and controls.

\begin{tabular}{|c|c|c|c|c|}
\hline Polymorphism & Cases $[\mathrm{n},(\%)]^{\mathrm{a}}$ & Controls $[\mathrm{n},(\%)]^{\mathrm{a}}$ & OR (CI 95\%) & P-value \\
\hline \multicolumn{5}{|l|}{ No. of CAG repeats } \\
\hline$\leq 21 \mathrm{CAGs}$ & $69(27.0)$ & $55(21.5)^{\mathrm{b}}$ & $3.0(1.8-5.0)$ & $<0.001$ \\
\hline$\geq 22$ CAGs & $39(15.2)$ & $93(36.3)$ & & \\
\hline \multicolumn{5}{|l|}{ No. of GGC repeats } \\
\hline$\leq 16$ GGCs & $42(17.3)$ & $38(15.6)^{\mathrm{c}}$ & $1.6(0.9-2.8)$ & 0.077 \\
\hline$\geq 17$ GGCs & $66(27.1)$ & $97(39.9)$ & & \\
\hline \multicolumn{5}{|l|}{ No. of CAG + GGC repeats } \\
\hline$\leq 21 \mathrm{CAGs}+\leq 16 \mathrm{GGCs}$ & $26(10.7)$ & $20(8.2)^{\mathrm{c}}$ & $1.8(0.9-3.5)$ & 0.067 \\
\hline Remaining repetitions ${ }^{\mathrm{d}}$ & $82(33.7)$ & $115(47.3)$ & & \\
\hline$\leq 21 \mathrm{CAGs}+\geq 17 \mathrm{GGCs}$ & $43(17.7)$ & $29(11.9)$ & $2.4(1.4-4.3)$ & 0.002 \\
\hline Remaining repetitions ${ }^{\mathrm{e}}$ & $65(26.7)$ & $106(43.6)$ & & \\
\hline
\end{tabular}

${ }^{\mathrm{a}}$ Mestizo individuals. ${ }^{\mathrm{b}} \mathrm{CAG}$ tandem repeat analysis performed on 148 (100\%) control individuals. ${ }^{\mathrm{c}} \mathrm{GGC}$ tandem repeat analysis performed on $91 \%$ of control individuals. ${ }^{\mathrm{d}}$ Combinations of repeats different from $\leq 21$ CAGs $+\leq 16$ GGCs and ${ }^{\mathrm{e}} \leq 21$ CAGs $+\geq 17$ GGCs.

Table III. Association of polymorphic CAG and GGC repeats with histopathological characteristics.

\begin{tabular}{|c|c|c|c|c|c|c|c|c|}
\hline \multirow[b]{2}{*}{ Variable } & \multicolumn{2}{|c|}{ CAG repeats } & \multirow{2}{*}{$\begin{array}{c}\text { OR } \\
(95 \% \mathrm{CI})\end{array}$} & \multirow[b]{2}{*}{ P-value } & \multicolumn{2}{|c|}{ GGC repeats } & \multirow{2}{*}{$\begin{array}{c}\text { OR } \\
(95 \% \mathrm{CI})\end{array}$} & \multirow[b]{2}{*}{ P-value } \\
\hline & $\geq 22(\%)$ & $\leq 21(\%)$ & & & $\geq 17(\%)$ & $\leq 16(\%)$ & & \\
\hline \multicolumn{9}{|c|}{ Tumor stage } \\
\hline $\mathrm{T} 1-\mathrm{T} 2 \mathrm{~b}$ & $19(21.8)$ & $20(23.0)$ & 4.8 & 0.002 & $25(28.7)$ & $14(16.1)$ & 1.1 & 0.880 \\
\hline $\mathrm{T} 2 \mathrm{c}-\mathrm{T} 4$ & $8(9.1)$ & $40(46.0)$ & $(1.8-2.7)$ & & $30(34.5)$ & $18(20.7)$ & $(0.5-2.6)$ & \\
\hline \multicolumn{9}{|c|}{ Gleason histological grade } \\
\hline $2-6$ & $19(21.8)$ & $27(31.0)$ & 2.9 & 0.037 & $27(31.0)$ & $19(21.8)$ & 0.7 & 0.350 \\
\hline $7-10$ & $8(9.2)$ & $33(37.9)$ & $(1.1-7.7)$ & & $28(32.2)$ & $13(14.9)$ & $(0.3-1.6)$ & \\
\hline \multicolumn{9}{|c|}{ PSA (ng/ml) } \\
\hline$<20$ & $19(20.2)$ & $35(37.2)$ & 1.3 & 0.661 & $37(39.4)$ & $17(18.1)$ & 2.2 & 0.070 \\
\hline$\geq 20$ & $12(12.8)$ & $28(29.8)$ & $(0.5-3.0)$ & & $20(21.3)$ & $20(21.3)$ & $(0.9-5.0)$ & \\
\hline \multicolumn{9}{|c|}{ Positive surgical margins } \\
\hline Absent & $20(29.0)$ & $39(36.5)$ & 1.2 & 1.000 & $38(55.1)$ & $21(30.4)$ & 0.8 & 1.000 \\
\hline Present & $3(4.4)$ & $7(10.1)$ & $(0.3-5.1)$ & & $7(10.1)$ & $3(4.4)$ & $(0.2-3.3)$ & \\
\hline \multicolumn{9}{|c|}{ Seminal vesicle invasion } \\
\hline Absent & $4(14.8)$ & $16(59.3)$ & 1.5 & 1.000 & $13(48.1)$ & $7(25.9)$ & 0.3 & 0.630 \\
\hline Present & $1(3.7)$ & $6(22.2)$ & $(0.1-16.3)$ & & $6(22.2)$ & $1(3.7)$ & $(0.03-3.1)$ & \\
\hline
\end{tabular}

OR, odds ratio; CI, confidence interval; PSA, prostate specific antigen.

been recorded in North American, Asian and African populations (10). However, the number of GGC repeats in affected individuals was 13-18, with an average of 16 .

The ranges and averages of the $\mathrm{CAG}$ and GGC repeats in control mestizo population are similar to those of Asian and Caucasian-European populations. This may be because the mestizo Ecuadorian population is considered a trihybrid, containing genes originated from America and descendants of Native Asians, Europeans and Africans (41).

A significant association between the presence of $\leq 21 \mathrm{CAGs,}$ and PC and histopathologic characteristics was determined.
Our results indicated that in mestizos the $\mathrm{PC}$ risk increased 2.99 times in males with $\leq 21 \mathrm{CAGs}$, which is consistent with the results of some other studies $(14,42)$. By contrast, some studies did not identify an association with this repetition $(15,16,43,44)$.

Few studies have identified a similar correlation with the Gleason score and $\leq 21 \mathrm{CAG}$ repeats. Thus, it is essential more research to establish an strong association between the Gleason score and the CAG repeats as a predictive parameter (45-47).

Several studies reported no association between the GGC repeat lengths, the PC risk, and pathological characteristics $(12,15,16)$, stating that there were no significant differences 
Table IV. Association of polymorphic CAG and GGC repeats with histopathological characteristics.

\begin{tabular}{|c|c|c|c|c|c|c|c|c|}
\hline \multirow[b]{2}{*}{ Variable } & \multicolumn{2}{|c|}{ Trinucleotide combined } & \multirow[b]{2}{*}{$\begin{array}{c}\text { OR } \\
(95 \% \mathrm{CI})\end{array}$} & \multirow[b]{2}{*}{$\mathrm{P}$} & \multicolumn{2}{|c|}{ Trinucleotide combined } & \multirow[b]{2}{*}{$\begin{array}{c}\text { OR } \\
(95 \% \mathrm{CI})\end{array}$} & \multirow[b]{2}{*}{$\mathrm{P}$} \\
\hline & $\begin{array}{c}\text { Remaining } \\
\text { individuals }^{\mathrm{a}}(\%)\end{array}$ & $\begin{array}{c}\leq 21 \text { CAGs }+ \\
\leq 16 \text { GGCs }(\%)\end{array}$ & & & $\begin{array}{c}\text { Remaining } \\
\text { individuals } \mathrm{s}^{\mathrm{b}}(\%)\end{array}$ & $\begin{array}{c}\leq 21 \text { CAGs }+ \\
\geq 17 \text { GGCs }(\%)\end{array}$ & & \\
\hline \multicolumn{9}{|c|}{ Tumor stage } \\
\hline $\mathrm{T} 1-\mathrm{T} 2 \mathrm{~b}$ & $30(34.5)$ & $9(10.3)$ & 1.5 & 0.400 & $28(32.2)$ & $11(12.6)$ & 2.8 & $<0.050$ \\
\hline $\mathrm{T} 2 \mathrm{c}-\mathrm{T} 4$ & 33 (37.9) & $15(17.2)$ & $(0.6-3.9)$ & & $23(26.4)$ & $25(28.7)$ & $(1.1-6.8)$ & \\
\hline \multicolumn{9}{|c|}{$\begin{array}{l}\text { Gleason histological } \\
\text { grade }\end{array}$} \\
\hline $2-6$ & $34(39.1)$ & $12(13.8)$ & 1.2 & 0.740 & $31(35.6)$ & $15(17.2)$ & 2.2 & 0.080 \\
\hline $7-10$ & $29(33.3)$ & $12(13.8)$ & $(0.5-3.0)$ & & $20(23.0)$ & $21(24.1)$ & $(0.9-5.2)$ & \\
\hline \multicolumn{9}{|c|}{ PSA (ng/ml) } \\
\hline$<20$ & $39(41.5)$ & $15(16)$ & 0.8 & 0.560 & $34(36.2)$ & $20(21.3)$ & 1.5 & 0.310 \\
\hline$\geq 20$ & $31(33)$ & $9(9.6)$ & $(0.3-1.9)$ & & $21(22.3)$ & $19(20.2)$ & $(0.7-3.5)$ & \\
\hline \multicolumn{9}{|c|}{$\begin{array}{l}\text { Positive surgical } \\
\text { margins }\end{array}$} \\
\hline Absent & $44(63.8)$ & $15(21.7)$ & 0.7 & 1.000 & $35(50.7)$ & $24(34.8)$ & 1.5 & 0.580 \\
\hline Present & 8 (11.6) & $2(2.9)$ & $(0.1-3.8)$ & & $5(7.2)$ & $5(7.2)$ & $(0.4-5.6)$ & \\
\hline \multicolumn{9}{|c|}{$\begin{array}{l}\text { Seminal vesicle } \\
\text { invasion }\end{array}$} \\
\hline Absent & $15(56.6)$ & $5(18.5)$ & 0.5 & 1.000 & $8(29.6)$ & $12(44.4)$ & 1.7 & 0.680 \\
\hline Present & $6(22.2)$ & $1(3.7)$ & $(0.1-5.2)$ & & $2(7.4)$ & $5(18.5)$ & $(0.3-10.8)$ & \\
\hline
\end{tabular}

a $>21$ CAGs + >16 GGCs; ${ }^{b}>21$ CAGs + < 17 GGCs. P, P-value; OR, odds ratio; CI, confidence interval; PSA, prostate specific antigen.

between cases and controls (48). This information is consistent with the results of the Ecuadorian population. However, other studies demonstrated that there is a 4.6 fold increased risk of developing PC when the GGC repetition is present $(14,49,50)$. Failure to determine an association suggests that the transcriptional activity of the AR gene does not differ when there are 13-17 GGC repeats; thus within this range, gene activity is normal (19).

No association of risk or protection between cases and controls was reported with $\leq 21$ CAGs $+\leq 16$ GGCs. Similarly, no association in the analysis of the clinicopathological variables was found. By contrast, the combination $\leq 21 \mathrm{CAGs}+\geq 17 \mathrm{GGCs}$ was correlated with a 2.42 times increased risk of developing PC. These results were consistent with other studies $(10,12,16,21)$.

The CAG and GGC repeats have been associated with PC in certain studies and discarded in others. As this is a complex and heterogeneous disease, an explanation of the discrepancy in the results is required. The main cause may be the variable androgen production in the different ethnic groups, the sample size or the criteria for selecting healthy controls. In Ecuador, indigenous communities represent $21 \%$ of the population (5), constituting a major ethnic group. The characterization of the CAG and GGC repeats in the indigenous population is of interest as to the best of our knowledge, these are the first records published. Thus, the average of 24 CAGs in the indigenous population was the highest average of the three groups. It demonstrated the similarity of this native population with Asian native populations, which are characterized by a low risk of developing PC. This may also suggest that the genetic ancestry of Native American groups originated in Asia, and were subsequently distributed throughout South America.

In conclusion, the risk of PC and the tumor characteristics differ in relation to the number CAG repeats, but not the number of GGC repeats. The information provided by the characterization of polymorphic CAG and GGC repeats must be interpreted with caution. Despite the results, the association between the number of trinucleotides and PC and clinical variables does not constitute definitive evidence for the repeats to be considered as molecular risk or poor prognosis markers.

In conclusion, the risk of PC and the tumor characteristics differ in relation to the number $\mathrm{CAG}$ repeats, but not the number of GGC repeats. Analysis of microsatellite instability in the AR gene in the Ecuadorian heterogeneous populations (Mestizo and indigenous) is important. However, the information provided by the characterization of polymorphic CAG and GGC repeats must be interpreted with caution. Despite the results, the association between the number of trinucleotides and PC, and clinical variables, such as tumor stage, does not constitute definitive evidence for the repeats to be considered as molecular risk or poor prognosis markers. Thus, further studies in other repeat length polymorphisms and AR gene expression are required.

\section{Acknowledgements}

This study was conducted with prostate cancer samples obtained from the Pathology Department of the Oncologic Hospital Solon Espinosa Ayala (SOLCA-Quito). 


\section{References}

1. Cancer Research UK, Worldwide cancer statistics, Cancer statistics 2014. http://www.cancerresearchuk.org/ cancer-info/cancerstats/world/. Accessed April 26, 2015.

2. Ferlay J, Shin H, Bray F, Forman D, Mathers C and Parkin DM: Estimates of worldwide burden of cancer in 2008: GLOBOCAN 2008. Int J Cancer 127: 2893-2917, 2010.

3. Jemal A, Bray F, Center MM, Ferlay J, Ward E and Forman D: Global cancer statistics. CA Cancer J Clin 61: 69-90, 2011.

4. Cueva P and Yépez J: Cancer epidemiology in Quito 2003-2005. Quito, Ecuador: National Cancer Registry (NCR), SOLCA, 2009.

5. World Health Organization: International Agency for Research on Cancer, GLOBOCAN 2012: Estimated cancer incidence, mortality and prevalence worldwide in 2012. http://globocan. iarc.fr/Default.aspx. Accessed April 26, 2015.

6. Faber PW, Kuiper GG, van Rooij HC, van der Korput JA, Brinkmann AO and Trapman J: The N-terminal domain of the human androgen receptor is encoded by one large exon. Mol Cell Endocrinol 61: 257-262, 1989.

7. Sleddens HF, Oostra BA, Brikmann AO and Trapman J: Trinucleotode (GGN) repeat polymorphism in the human androgen receptor (AR) gene. Hum Mol Genet 2: 493, 1993.

8. Mangelsdorf DJ, Thummel C, Beato M, Herrlich P, Schütz G, Umesono K, Blumberg B, Kastner P, Mark M, Chambon P and Evans RM: The nuclear receptor superfamily: The second decade. Cell 83: 835-839, 1995

9. Tut TG, Ghadessy FJ, Trifiro MA, Pinsky L and Yong EL: Long polyglutamine tracts in the androgen receptor are associated with reduced trans-activation, impaired sperm production and male infertility. J Clin Endocrinol Metab 82: 3777-3782, 1997.

10. Irvine RA, Yu MC, Ross RK and Coetzee GA: The CAG and GGC microsatellites of the androgen receptor gene are linkage disequilibrium in men with prostate cancer. Cancer Res 55: 1937-1940, 1995

11. Giovannucci E, Stampfer MJ, Kritivas K, Brown M, Dahl D, Brufsky A, Talcott J, Hennekens CH and Kantoff PW: The CAG repeat within the androgen receptor gene and its relationship to prostate cancer. Proc Natl Acad Sci USA 94: 3320-3323, 1997.

12. Ingles SA, Ross RK, Yu MC, Irvine RA, La Pera G, Haile RW and Coetzee GA: Association of prostate cancer risk with genetic polimorphims in vitamin D receptor and androgen receptor J Natl Cancer Inst 89: 166-170, 1997.

13. Stanford JL, Just JJ, Gibbs M, Wicklund KG, Neal CL, Blumenstein BA and Ostrander EA: Polymorphic repeats in the androgen receptor gene: Molecular markers of prostate cancer risk. Cancer Res 57: 1194-1198, 1997.

14. Hakimi JM, Schoenberg MP, Rondinelli RH, Piantadosi S and Barrack ER: Androgen receptor variants with short glutamine or glycine repeats may identify unique subpopulations of men with prostate cancer. Clin Cancer Res 3: 1599-1608, 1997.

15. Cicek MS, Conti DV, Curran A, Neville PJ, Paris PL, Casey G and Witte JS: Association of prostate cancer risk and aggressiveness to androgen pathway genes: SRD5A2, CYP17 and the AR. Prostate 59: 69-76, 2004.

16. Salinas CA, Austin MA, Ostrander EO and Stanford JL: Polymorphisms in the androgen receptor and the prostate-specific antigen genes and prostate cancer risk. Prostate 65: 58-65, 2005.

17. Kristal AR, Price DK, Till C, Schenk JM, Neuhouser ML, Ockers S, Lin DW, Thompson IM and Figg WD: Androgen receptor CAG repeat length is not associated with the risk of incident symptomatic begin prostatic hyperplasia: Results from the prostate cancer prevention trial. Prostate 70: 584-590, 2010.

18. Platz EA, Giovannucci E, Dahl DM, Krithivas K, Hennekens CH, Brown M, Stampfer MJ and Kantoff PW: The androgen receptor gene GGN microsatellite and prostate cancer risk. Cancer Epidemiol Biomarkers Prev 7: 379-384, 1998.

19. Ding D, Xu L, Menon M, Reddy GP and Barrack ER: Effect of GGC (glycine) repeat length polymorphism in the human androgen receptor on androgen action. Prostate 62: 133-139, 2005.

20. Edwards SM, Badzioch MD, Minter R, Hamoudi R, Collins N, Ardern-Jones A, Dowe A, Osborne S, Kelly J, Shearer R, et al: Androgen receptor polymorphisms: Association with prostate cancer risk, relapse and overall survival. Int $\mathrm{J}$ Cancer 84 $458-465,1999$.
21. Chen C, Lamhanzi N, Weis NS, Etzioni R, Dightman DA, Barnett M, DiTommaso D and Goodman G: Androgen receptor polymorphisms and the incidence of prostate cancer. Cancer Epidemiol Biomarkers Prev 11: 1033-1040, 2002

22. López-Cortés A, Echeverría C, Oña-Cisneros F, Sánchez ME, Herrera C, Cabrera-Andrade A, Rosales F, Ortiz M and Paz-Y-Miño C: Breast cancer risk associated with gene expression and genotype polymorphisms of the folate-metabolizing MTHFR gene: A case-control study in a high altitude Ecuadorian mestizo population. Tumor Biol 36: 6451-6461, 2015.

23. Ellegren H: Microsatellites: Simple sequences with complex evolution. Nat Rev Genet 5: 435-445, 2004.

24. Albà MM and Guigó R: Comparative analysis of amino acid repeats in rodents and humans. Genome Res 14: 549-555, 2004.

25. Sawaya ME and Shalita AR: Androgen receptor polymorphisms (CAG repeat lengths) in androgenetic alopecia, hirsutism and acne. J Cutan Med Surg 3: 9-15, 1998.

26. Shah NA, Antoine HJ, Pall M, Taylor KD, Azziz R and Goodarzi MO: Association of androgen receptor CAG repeat polymorphism and polycystic ovary syndrome. J Clin Endocrinol Metab 93: 1939-1945, 2008

27. Mehdipour P, Pirouzpanah S, Kheirollahi M and Atri M: Androgen receptor gene $\mathrm{CAG}$ repeat polymorphism and breast cancer risk in Iranian women: A case-control study. Breast J 17: 39-46, 2011.

28. MacLean HE, Choi WT, Rekaris G, Warne GL and Zajac JD: Abnornal androgen receptor binding affinity in subjects with Kennedy's disease (spinal and bulbar muscular atrophy). J Clin Endocrinol Metab 80: 508-516, 1995.

29. Fesaǔ O, Kravchenko SA, Tyrkus MIa, Makukh GV, Zinchenko VM, Strelko GV and Livshits LA: Androgen receptor CAG gene polymorphism in men with azoospermia and oligozoospermia in Ukraine. Tsitol Genet 43: 45-51, 2009 (In Russian).

30. Radpour R, Rezaee M, Tavasoly A, Solati S and Saleki A: Association of long polyglycine tracts (GGN repeats) in exon 1 of the androgen receptor gene with cryptorchidism and penile hypospadias in Iranian patients. J Androl 28: 164-169, 2007.

31. Aschim EL, Nordenskjöld A, Giwercman A, Lundin KB, Ruhayel Y, Haugen TB, Grotmol T and Giwercman YL: Linkage between cryptorchidism, hypospadias and GGN repeat length in the androgen receptor gene. J Clin Endocrinol Metab 89: 5105-5109, 2004.

32. Sartor O, Zheng Q and Eastham JA: Androgen receptor gene CAG repeat length varies in a race-specific fashion in men without prostate cancer. Urology 53: 378-380, 1999.

33. Kittles RA, Young D, Weinrich S, Hudson J, Argyropoulos G, Ukoli F, Adams-Campbell L and Dunston GM: Extent of linkage disequilibrium between the androgen receptor gene CAG and GGC repeats in human populations: Implications for prostate cancer risk. Hum Genet 109: 253-261, 2001.

34. Krausz C An encore for the repeats: New insights into an old genetic variant. J Clin Endocrinol Metab 97: 764-767, 2012.

35. Paz-y-Miño C, Witte T, Robles P, Llumipanta W, Díaz M and Arévalo M: Association among polymorphisms in the steroid 5alpha-reductase type II (SRD5A2) gene, prostate cancer risk, and pathologic characteristics of prostate tumors in an Ecuadorian population. Cancer Genet Cytogenet 189: 71-76, 2009.

36. López-Cortés A, Jaramillo-Koupermann G, Muñoz MJ, Cabrera A, Echeverría C, Rosales F, Vivar N and Paz-y-Miño C: Genetic polymorphisms in MTHFR (C677T, A1298C), MTR (A2756G) and MTRR (A66G) genes associated with pathological characteristics of prostate cancer in the Ecuadorian population. Am J Med Sci 346: 447-454, 2013.

37. Ribeiro ML, Santos A, Carvalho-Salles AB and Hackel C: Allelic frequencies of six polymorphic markers for risk of prostate cancer. Braz J Med Biol Res 35: 205-213, 2002.

38. Madjunkova S, Eftimov A, Georgiev V, Petrovski D, Dimovski A and Plaseska-Karanfilska D: CAG repeat number in the androgen receptor gene and prostate cancer. Balkan J Med Genet 15: 31-36, 2012.

39. Beilin J, Harewood L, Frydenberg M, Mameghan $\mathrm{H}$, Martyres RF, Farish SJ, Yue C, Deam DR, Byron KA and Zajac JD: A case-control study of the androgen receptor gene CAG repeat polymorphism in Australian prostate carcinoma subjects. Cancer 92: 941-949, 2001.

40. Esteban E, Rodon N, Via M, Gonzalez-Perez E, Santamaria J, Dugoujon JM, Chennawi FE, Melhaoui M, Cherkaoui M, Vona G, et al: Androgen receptor CAG and GGC polymorphisms in Mediterraneans: Repeat dynamics and population relationships. J Hum Genet 51: 129-136, 2006. 
41. Baeta M, Núñez C, Aznar JM, Sosa C, Casalod Y, Bolea M, González-Andrade F, de Pancorbo MM and Martínez-Jarreta B: Analysis of $10 \mathrm{X}$-STRs in three population groups from Ecuador. Forensic Sci Int Genet 7: e19-e20, 2013

42. Hsing AW, Gao YT, Wu G, Wang X, Deng J, Chen YL, Sesterhenn IA, Mostofi FK, Benichou J and Chang C: Polymorphic CAG and GGN repeat lengths in the androgen receptor gene and prostate cancer risk: A population-based case-control study in China. Cancer Res 60: 5111-5116, 2000.

43. Lange EM, Chen H, Brierley K, Livermore H, Wojno KJ, Langefeld $\mathrm{CD}$, Lange $\mathrm{K}$ and Cooney KA: The polymorphic exon 1 androgen receptor CAG repeat in men with a potential inherited predisposition to prostate cancer. Cancer Epidemiol Biomarkers Prev 9: 439-442, 2000.

44. Price DK, Chau CH, Till C, Goodman PJ, Baum CE, Ockers SB, English BC, Minasian L, Parnes HL, Hsing AW, et al: Androgen receptor CAG repeat length and association with prostate cancer risk: Results from the prostate cancer prevention trial. J Urol 184 2297-3302, 2010.

45. Giovannucci E: Is the androgen receptor CAG repeat length significant for prostate cancer? Cancer Epidemiol Biomarkers Prev 11: 985-986, 2002.
46. Correa-Cerro L, Wöhr G, Häussler J, Berthon P, Drelon E, Mangin P, Fournier G, Cussenot O, Kraus P, Just W, et al: (CAG) nCAA and GGN repeats in the human androgen receptor gene are not associated with prostate cancer in a French-German population. Eur J Hum Genet 7: 357-362, 1999.

47. Platz EA, Leitzmann MF, Rifai N, Kantoff PW, Chen YC, Stampfer MJ, Willett WC and Giovannucci E: Sex steroid hormones and the androgen receptor gene CAG repeat and subsequent risk of prostate cancer in the prostate-specific antigen era. Cancer Epidemiol Biomarkers Prev 14: 1262-1269, 2005.

48. Alptekin D, Izmirli M, Bayazit Y, Luleyap HU, Yilmaz MB, Soyupak B, Erkoc MA and Tansug Z: Evaluation of the effects of androgen receptor gene trinucleotide repeats and prostate-specific antigen gene polymorphisms on prostate cancer. Genet Mol Res 11: 1424-1432, 2012.

49. Narod SA, Dupont A, Cusan L, Diamond P, Gomez JL, Suburu R and Labrie F: The impact of family history on early detection of prostate cancer. Nat Med 1: 99-101, 1995.

50. Monroe KR, Yu MC, Kolonel LN, Coetzee GA, Wilkens LR, Ross RK and Henderson BE: Evidence of an X-linked or recessive genetic component to prostate cancer risk. Nat Med 1: 827-829, 1995. 